\title{
(S)-Binam-L-prolinamide as organocatalyst for the enantioselective conjugate addition of $\alpha$-alkoxyketones to $\beta$-nitrostyrene derivatives
}

\author{
Gabriela Guillena,* Carmen Nájera, Santiago F. Viózquez and Miguel Yus \\ Departamento de Química Orgánica and Instituto de Síntesis Orgánica (ISO), \\ Universidad de Alicante, Apartado 99, 03080 Alicante, Spain \\ E-mail: gabriela.guillena@ua.es,cnajera@ua.es
}

\section{Dedicated to Professor Julio Alvarez-Builla on occasion of his $65^{\text {th }}$ birthday}

\begin{abstract}
(S)-Binam-L-prolinamide $(20 \mathrm{~mol} \%)$ catalyze the enantioselective Michael addition of several $\alpha$ alkoxyketones to different $\beta$-nitrostyrene derivatives. In the study of the optimization of the reaction conditions it was found surprisingly that hexane is the solvent of choice to carry out such transformation. Under these reaction conditions, the corresponding highly functionalized products were obtained in good yields (up to 90\%), mainly as syn-diastereomers with moderate diastereoand enantioselectivities.
\end{abstract}

Keywords: Asymmetric synthesis, conjugate addition, nitroolefins, organocatalysis, prolinamides

\section{Introduction}

Asymmetric conjugate additions of nucleophiles to electron-poor alkenes, also known as Michaeltype reactions, are one of the most important and attractive $\mathrm{C}-\mathrm{C}$ bond formation reactions, which allows the synthesis of useful products in a stereocontrolled manner. ${ }^{1}$ Several strategies could be applied to achieve this task, with the use of catalytic methods being the most attractive alternative to produce these compounds with high selectivity and efficiency. ${ }^{2}$ Numerous advances in the use of chiral transition metal catalysts have been achieved for this purpose in the last century. ${ }^{3}$ On the other hand, the use of metal-free processes, so-called organocatalysis, ${ }^{4}$ has emerged in the last decade as a powerful environmentally benign strategy to perform this reaction, ${ }^{5}$ as well as other C$\mathrm{C}$ or $\mathrm{C}$-heteroatom ${ }^{6}$ bond formation reactions. This procedure has several advantages related to handling, cost and safety issues due to the stability and availability of the catalysts, less demanding reaction conditions required compared to the use of transition metal catalysts and reduced toxicity of the final products, proving a highly efficient chemical process for the synthesis of complex 
molecules. ${ }^{7}$ In this context, the asymmetric 1,4-addition of ketones and aldehydes to nitrostyrenes led to the formation of interesting chiral $\gamma$-nitrocarbonyl compounds bearing at least two stereogenic centers. These chiral compounds are valuable building blocks in organic synthesis, since the nitro functionality can easily be transformed into a carboxylic acid, ketone, nitrile oxide, or amine, etc. ${ }^{8}$ However, the use of $\alpha$-alkoxyketones as nucleophiles, which in the aldol ${ }^{9}$ and Mannich ${ }^{10}$ organocatalyzed reactions has led to high regioselectivities and stereoselectivities, gave diverse results when they were used as donors in the Michael addition to nitrostyrenes. Thus, while the use of the bypyrrolidine 1 ( $15 \mathrm{~mol} \%$, Scheme 1) as catalyst in the reaction between $\alpha$ hydroxyacetone to aromatic nitroolefins in chloroform gave mainly the anti-isomer in excellent enantioselectivities after $7 \mathrm{~d}$ at room temperature $(56-82 \%$ de, $96-98 \%$ ee), the use of $\alpha$ methoxyacetone $(\mathrm{R}=\mathrm{Me})$ under similar reaction conditions provided the syn-isomer as the main product $\left(66 \%\right.$ de) with moderate enantioselectivity $\left(69 \%\right.$ ee) ${ }^{11}$ When the reaction was carried out in $N$-methylpyrrolidinone (NMP) as solvent in the presence of 10 equiv of water and $p$ methylphenylsulphonic acid $(15 \% \mathrm{~mol})$ using the primary amine $2(30 \mathrm{~mol} \%)$ as catalyst in the reaction between $\alpha$-hydroxyacetone and $\beta$-nitrostyrene, the anti-isomer (33\% de) was achieved as the main product with low enantioselectivity $\left(29 \%\right.$ ee). ${ }^{12}$ The use of catalyst $3(20 \mathrm{~mol} \%$ in isopropanol at $\left.0{ }^{\circ} \mathrm{C}\right)^{13}$ and prolinamide $4(20 \mathrm{~mol} \%$ in the presence of $20 \mathrm{~mol} \%$ of $p$-nitrobenzoic acid in $\mathrm{CH}_{2} \mathrm{Cl}_{2}$ at rt), ${ }^{14}$ led mainly to the formation of the syn-isomer (de up to $50 \%$ ) in moderate enantioselectivity (ee up to $46 \%$ ee). However, improved results were obtained when sulphonamide 3 as catalyst and tert-butyldimethylsilyl protected $\alpha$-hydroxyacetone $(\mathrm{R}=$ TBDMS in Scheme 1)

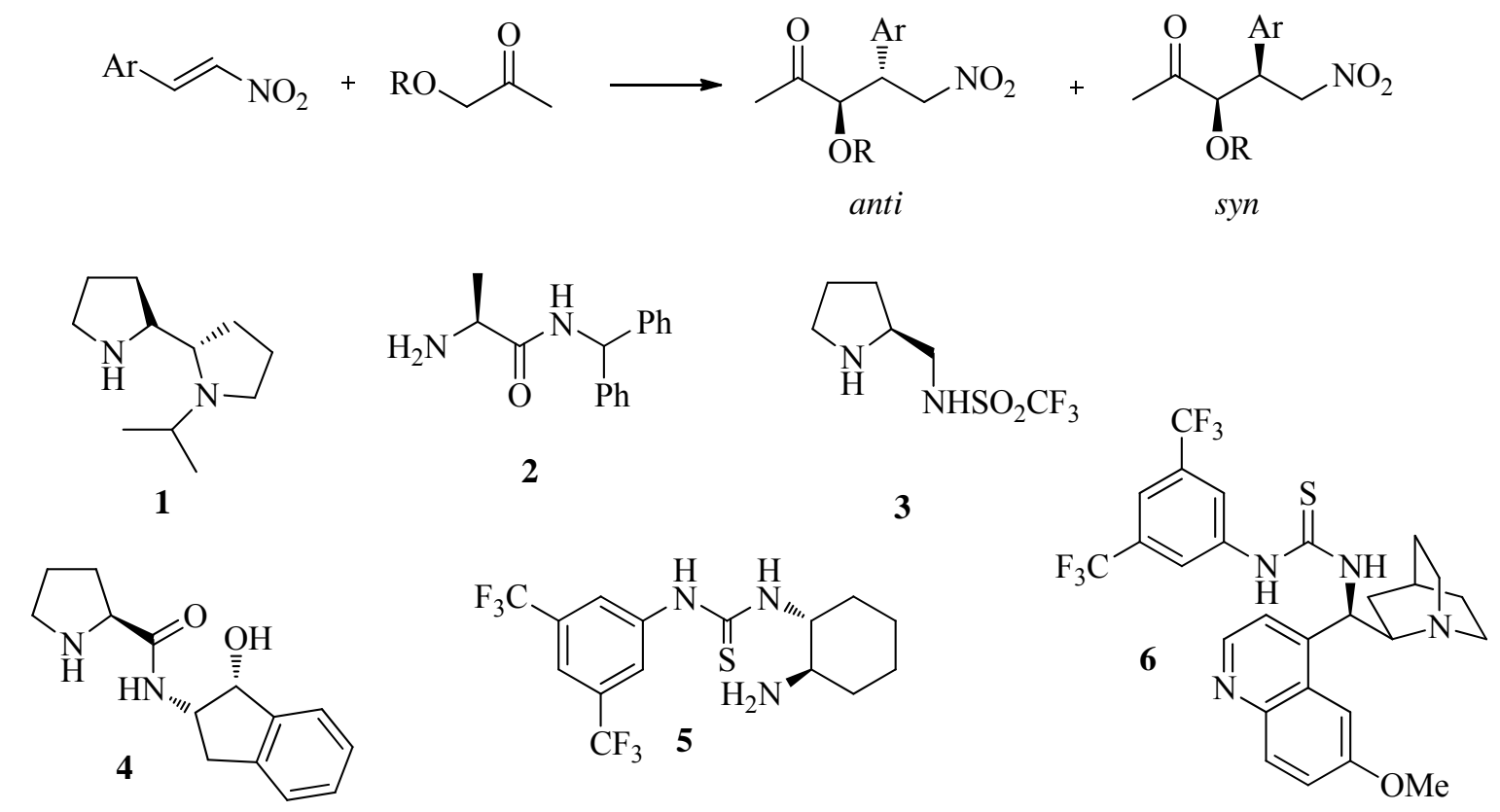

Scheme 1. Michael reaction between $\alpha$-alkoxyacetones and $\beta$-nitrostyrenes. 
were used in this transformation ( $90 \%$ de and $86 \%$ ee). Also, the use of thiourea derivatives as catalysts in the reaction between $\alpha$-methoxyacetone and $\beta$-nitrostyrene provided different results. Thus, while compound 5 (20 mol\%) in the presence of 4-(dimethylamino)pyridine (DMAP, 20 $\mathrm{mol} \%)$ in chloroform at room temperature gave the anti-isomer in low diasteroselectivity $(33 \% \mathrm{de})$ and moderate enantioselectivity ( $41 \%$ ee), ${ }^{15}$ the use of the quinidine thiourea 6 in combination with proline ( $5 \mathrm{~mol} \%$ of each) in benzene at $\mathrm{rt}$ led mainly to the formation of the syn-isomer in moderate diastereoselectivity $\left(64 \%\right.$ de) and high enantioselectivity $\left(90 \%\right.$ ee) ${ }^{16}$

As in the direct aldol reaction catalyzed by Binam-prolinamides such as $7^{17}$ and $8^{18}$ between aldehydes and alkoxyacetones provided the expected products with high regio-, diastereo- and enantioselectivity using different reaction media, ${ }^{17 \mathrm{~d}, \mathrm{e}, \mathrm{i}}$ including solvent-free reaction conditions, ${ }^{17 \mathrm{j}, \mathrm{k}}$ we thought that the application of these catalyst to the Michael addition of $\alpha$-alkoxyketones as nucleophiles to $\beta$-nitrostyrene derivatives would be of interest.

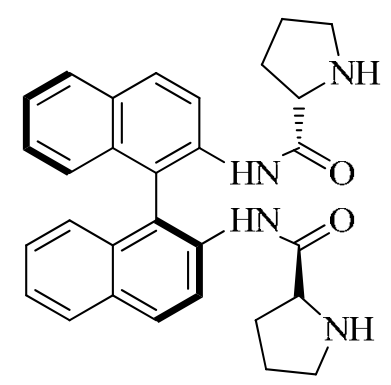

7

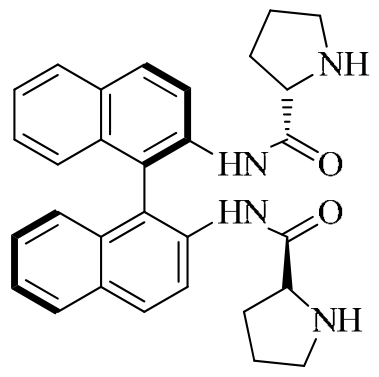

9<smiles></smiles>

8<smiles>O=C(Nc1ccc2ccccc2c1-c1c(NC(=O)N2CCCN2)ccc2ccccc12)[C@@H]1CCCN1</smiles>

ent-9

\section{Results and Discussion}

Catalysts $\left(S_{a}\right)$-Binam-L-Pro 7 and $N$-tosyl-( $\left(S_{a}\right)$-Binam-L-Pro 8 were synthesized as previously described $^{17 a, 18 b}$ starting form 2,2'-diamino-1,1'-binaphthalene (Binam) and L-proline. Also the diasteromeric catalysts 9 and ent-9 were prepared following similar procedures. The optimization of the reaction conditions were performed by the addition of $\alpha$-methoxyacetone to $\beta$-nitrostyrene as reaction model (Table 1), using $20 \mathrm{~mol} \%$ of catalyst 7 and NMP as solvent. We have previously found for the aldol reaction that a high acceleration was achieved when the reaction was cocatalyzed by a carboxylic acid, ${ }^{17,18}$ therefore $20 \mathrm{~mol} \%$ of $p$-nitrobenzoic acid was added as 
cocatalyst at room temperature, achieving the expected product only after $6 \mathrm{~h}$. nearly in a quantitative yield but with a moderate syn-diastereoselectivity $(38 \%$ de) and with low enantioselectivity (Table 1, entry 1).

Table 1. Optimization of the reaction conditions for the Michael addition of $\alpha$-methoxyacetone to $\beta$-nitrostyrene ${ }^{\mathrm{a}}$

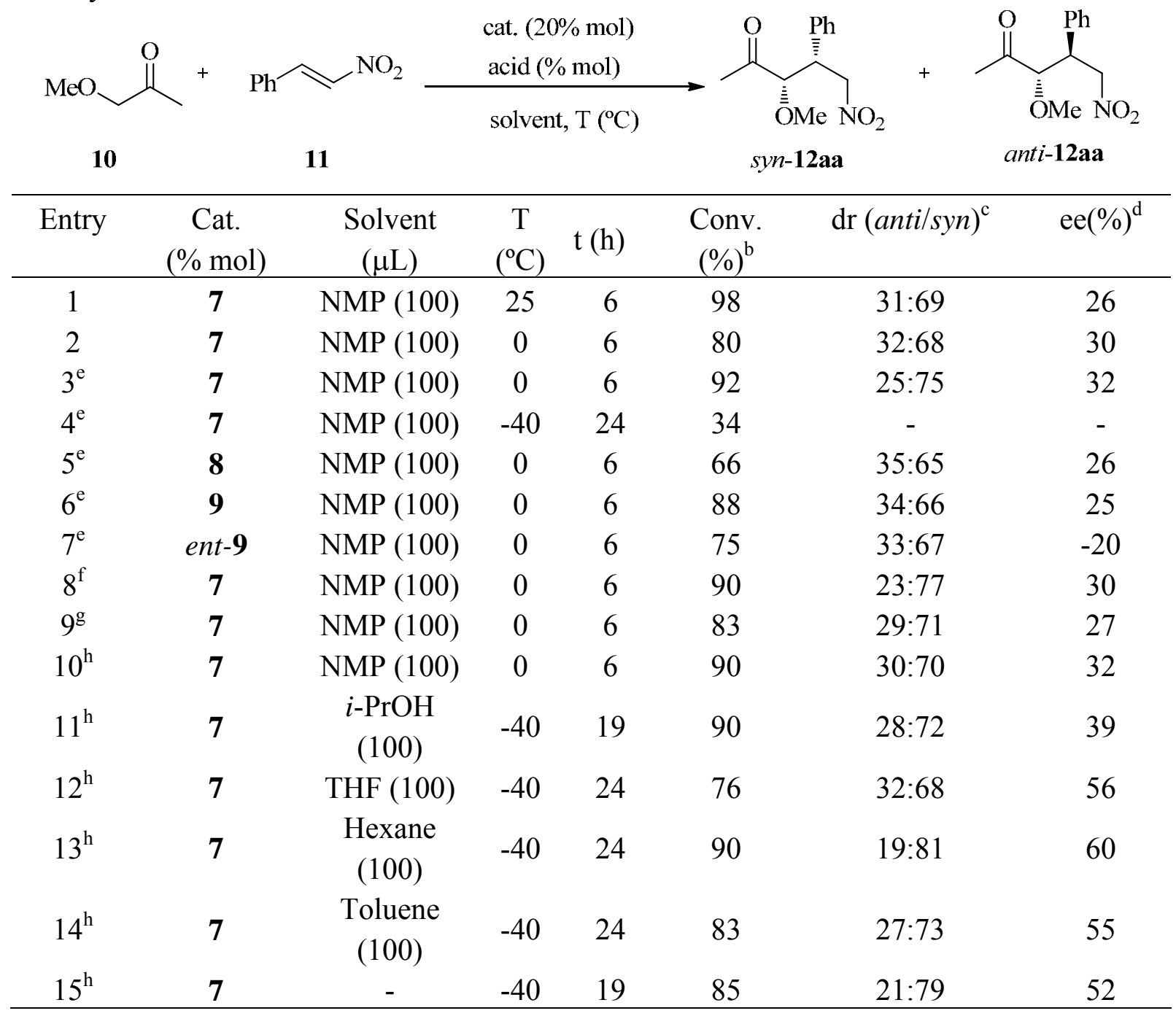

${ }^{\mathrm{a}}$ The reactions were carried out using $\beta$-nitrostyrene $(0.25 \mathrm{mmol}), \alpha$-methoxyacetone $(1.25 \mathrm{mmol})$, catalyst $(20 \% \mathrm{~mol})$ and acid $(20 \% \mathrm{~mol})$.

${ }^{\mathrm{b}}$ Conversion based on the unreacted $\beta$-nitrostyrene determined by ${ }^{1} \mathrm{H}$ NMR of the crude mixture.

${ }^{\mathrm{c}}$ Determined by ${ }^{1} \mathrm{H}$ NMR of the crude mixture.

${ }^{\mathrm{d}}$ Determined by HPLC for the syn-isomer.

${ }^{\mathrm{e}} 10 \mathrm{~mol} \%$ of acid was used.

${ }^{\mathrm{f}}$ Benzoic acid (10 mol\%) was used.

${ }^{\mathrm{g}}$ Acetic acid (10 mol\%) was used.

${ }^{\mathrm{h}}$ The reaction was carried out in the absence of acid. 
In order to increase the enantioselectivity of the process, the temperature was decreased to $0{ }^{\circ} \mathrm{C}$, which led only to a slightly increase of the enantioselectivity of the product (Table 1, entry 2). The use of an excessive amount of acid could have a detrimental effect on the results, thus this amount was reduced to $10 \mathrm{~mol} \%$, and a small improvement of the diastereo- and enantioselectivity was observed under these new reaction conditions (Table 1, entry 3 ). A further decrease of the reaction temperature to $-40{ }^{\circ} \mathrm{C}$ was attempted, but unfortunately under these reaction conditions, a low conversion was observed (Table 1, entry 4). Next, the influence of the structure of the catalyst was evaluated by performing the reaction under similar conditions but using compound 8 ( $20 \mathrm{~mol} \%)$, leading to poorer results in terms of conversion, diastereo- and enantioselectivy (Table 1, entry 5). Then, the effect of the axial stereoelement in the stereochemical outcome of the reaction was studied. Thus, when the diasteromeric catalyst $\left(R_{\mathrm{a}}\right)$-Binam-L-Pro 9 was used, the product syn-12aa was obtained with high conversion (88\%), although with lower diastereo- and enantioselectivity (Table 1, entry 6), showing that catalyst 7 was the matched diastereomer to perform this transformation. The use of the corresponding enantiomeric catalyst ent-9 $(20 \mathrm{~mol} \%)$ under similar reaction conditions led, as expected, to the product syn-12aa but with opposite configuration (Table 1, entry 7). Once the best catalyst 7 was found, the effect of the addition of a carboxylic acid as cocatalyst was evaluated. Thus, when weak acids, such as benzoic or acetic acid were used (10 mol\%) the achieved results were not improved (Table 1, entries 8 and 9). Furthermore, when the reaction was performed in the absence of acid, similar results to those achieve in the presence of 10 mol\% of $p$-nitrobenzoic acid were obtained (Table 1, compare entries 3 and 10), showing that for this transformation the use of an acid as cocatalysts was not necessary. Under these new reaction conditions ( $20 \mathrm{~mol} \%$ of catalyst 7 ), the use of a different solvent to perform the reaction was tested. Thus, the reaction in isopropanol at $-40{ }^{\circ} \mathrm{C}$ gave after $19 \mathrm{~h}$ the expected product syn-12aa ( $\left.44 \% \mathrm{de}\right)$ with a small increase of the achieved enantioselectivity (Table 1, entry 11). The use of a less polar solvent such THF, hexane or toluene (Table 1, entries 12-14) led to a further improvement of the enantioselectivity, with the best results $(62 \%$ de, $60 \%$ ee) being obtained using hexane as reaction medium (Table 1, entry 13). This transformation could be also performed under solvent-free conditions at $-40{ }^{\circ} \mathrm{C}$, although a slightly lower conversion $(85 \%)$, diastereo- $(58 \%$ de) and enantioselectivity ( $52 \%$ ee) were achieved under these reaction conditions (Table 1 , entry 15 ).

Under the optimal reaction conditions, $20 \mathrm{~mol} \%$ of catalyst 7 in hexane at $-40{ }^{\circ} \mathrm{C}$ (Table 1 , entry 13), the reaction were performed using $\alpha$-methoxyacetone and $\alpha$-hydroxyacetone as nucleophiles and several $\beta$-nitrostyrene derivatives as Michael acceptors (Table 2).

The use of $\alpha$-methoxyacetone as nucleophile in the Michael reaction with several $\beta$ nitrostyrene derivatives gave mainly the corresponding syn-isomers, with moderate diastereo- and enantioselectivity (Table 2, entries 1-3). Surprisingly, the reaction with $\beta$-nitrostyrene derivatives containing electron-withdrawing groups, was slower than the reaction with 11a (Table 2, entries 2 and 3). Thus, the reaction of 1-chloro-4-(2-nitrovinyl)benzene 11b with $\alpha$-methoxyacetone 10a gave product 12ab after $48 \mathrm{~h}$ in $82 \%$ yield, with moderate diastereo- and enantioselectivity (54\% de and $40 \%$ ee, Table 2 , entry 2 ). Better enantioselectivity ( $60 \%$ ee) was achieved after $48 \mathrm{~h}$ for the product 12ac mainly as the syn-isomer ( $24 \%$ de, Table 2 , entry 3$)$. For all these compound, the 
obtained enantioselectivities for the corresponding anti-isomers were superior to those achieved for the syn-product, being obtained with up to $82 \%$ ee for anti-12ac.

When $\alpha$-hydroxyacetone $\mathbf{1 0 b}$ was used as Michael donor in the reaction with different $\beta$ nitrostyrene derivatives, the reaction must be performed at $0{ }^{\circ} \mathrm{C}$, because at lower temperatures the process was too slow. Under these reaction conditions, the use of $\beta$-nitrostyrene 11a as electrophile led mainly to the formation of syn-12ba (54\% de) in good yield $(87 \%)$ albeit with moderate enantioselectivity (54\% ee, Table 2, entry 4). The use of compound 11b as Michael acceptor gave the corresponding $\alpha$-hydroxy- $\gamma$-nitropentane derivative $\mathbf{1 2 b b}$ in low diastereo- and enantioselectivity (30\% de, 36\% ee), while the use of $\beta$-nitrostyrene derivative 11c led mainly to syn-12bc in 50\% de and 46\% ee (Table 1, entries 5 and 6). As in the previous cases, the achieved enantioselectivities for the corresponding anti-isomers were higher compared to the major synisomer. For these compounds, the separation of both diastereoisomers was possible by column chromatography.

Table 2. Michael addition of $\alpha$-alkoxyacetones to $\beta$-nitrostyrenes ${ }^{\mathrm{a}}$

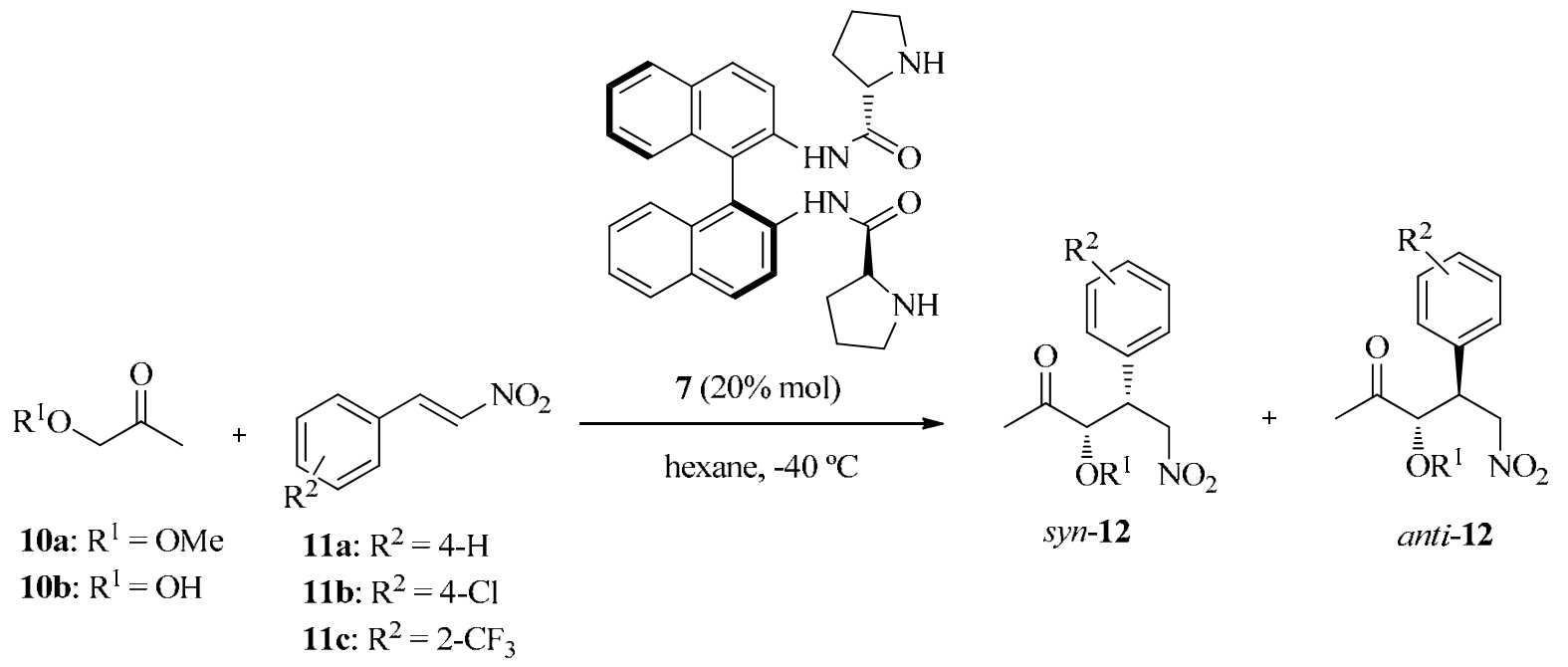

\begin{tabular}{|c|c|c|c|c|c|c|}
\hline Entry & Major Product & $\mathrm{t}(\mathrm{h})$ & $\begin{array}{l}\text { Yield } \\
(\%)^{b}\end{array}$ & $\mathrm{dr}(\text { anti/syn })^{\mathrm{c}}$ & $e_{s y n}(\%)^{d}$ & $e_{a n t i}(\%)^{\mathrm{d}}$ \\
\hline 1 & & 24 & 90 & $19: 81$ & 60 & 62 \\
\hline
\end{tabular}


Table 2. Continued

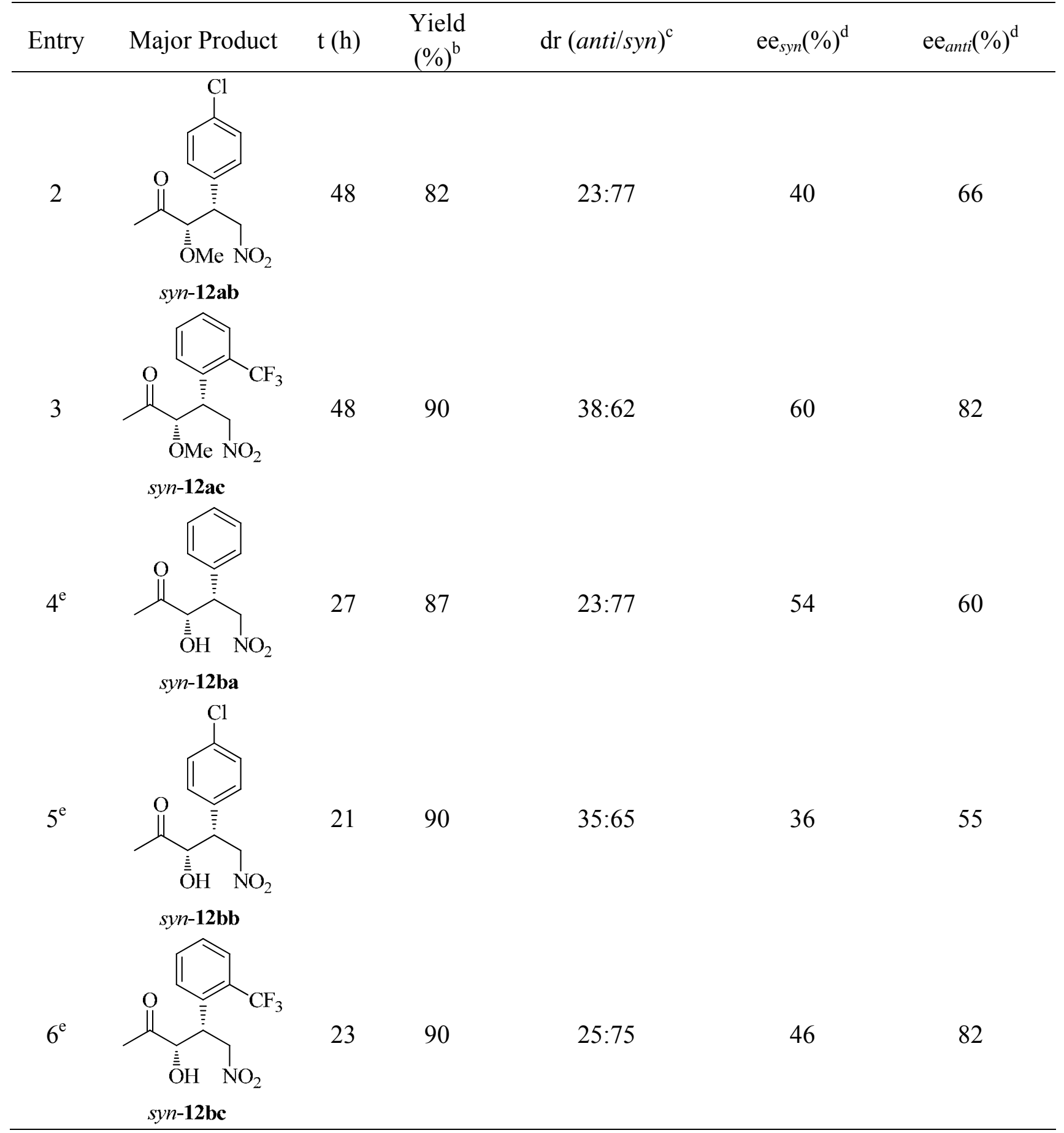

${ }^{\mathrm{a}}$ The reactions were carried out using $\beta$-nitrostyrene derivative $(0.25 \mathrm{mmol}), \alpha$-alkoxyketone $(1.25$ mmol), catalyst $7(20 \% \mathrm{~mol})$ in $n$-hexane at $-40^{\circ} \mathrm{C}$, otherwise stated.

${ }^{b}$ Yield after purification by column chromatography.

${ }^{c}$ Determined by ${ }^{1} \mathrm{H}$ NMR of the crude mixture.

${ }^{\mathrm{d}}$ Determined by HPLC.

${ }^{\mathrm{e}}$ The reaction was carried out at $0{ }^{\circ} \mathrm{C}$ 
Finally, other alkyl ketones such as cyclohexanone, acetone, butanone or 3-pentanone were used as nucleophiles in the Michael addition to $\beta$-nitrostyrene. Although, the corresponding addition products were formed in good yields, for all tested reaction conditions in the case of cyclohexanone and acetone, only racemic mixtures were obtained. For butanone and 3-pentanone, the best results were obtained in NMP as solvent in the presence of $20 \mathrm{~mol} \%$ of catalyst 4 and 20 mol\% of $p$-nitrobenzoic acid at room temperature achieving the expected syn-products in high diastereoselectivity ( $80 \%$ de) but in only $28 \%$ and $49 \%$ ee, respectively.

The previously reported X-ray structure for catalyst $7^{17 \mathrm{k}}$ gave a dihedral angle between the both naphthyl groups in the catalyst of $81.51^{\circ}$. Furthermore, the results of the ESI-MS mechanistic studies for the aldol reaction ${ }^{17 \mathrm{k}}$ showed that both proline residues present in the catalyst were involved in the formation of the enamine intermediate but only one of the enemine reacted with the electrophile. Based on these previous observations and the present experimental results, a model for the transition state, involving the enamine intermediate with only one intramolecular hydrogen bond of the hydrogen of the amide group with the nitro group of the electrophile could be proposed.

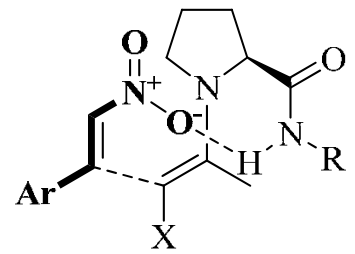

As conclusion, the catalyst 7 (20 mol\%) was able to promote the enantioselective Michael addition of several $\alpha$-alkoxyketones to different $\beta$-nitrostyrene derivatives. The reaction was carried out in $n$-hexane as solvent at $-40{ }^{\circ} \mathrm{C}$ or $0{ }^{\circ} \mathrm{C}$ depending on the nucleophilic $\alpha$-alkoxyketones used. Good yields (87-90\%) were obtained for the corresponding $\alpha$-hydroxy- $\gamma$-nitropentane derivatives. Under these reaction conditions, moderate diastereoselectivities were achieved (up to $62 \% \mathrm{de}$ ), although in most cases it was possible to isolate both diasteroisomers. While the enantioselectivities obtained for the minor anti-isomers were high (up to $82 \%$ ee), those reached for the major syn-isomers were only moderate (up to $60 \%$ ee).

\section{Experimental Section}

General. All reactions for the catalyst preparation were carried out under argon. NMP, THF, $i$ $\mathrm{PrOH}, \mathrm{CH}_{2} \mathrm{Cl}_{2}, n$-hexane and toluene and all others reagents were commercially available and used without further purification. Catalysts $7,{ }^{17 \mathrm{a}} \mathbf{8}^{18 \mathrm{~b}}, \mathbf{9}^{17 \mathrm{a}}$ and ent-9 $\mathbf{9}^{17 \mathrm{a}}$ were prepared according to the previously reported procedures. Only the structural most important peaks of the IR spectra (recorded on a Nicolet Impact 400D) are listed. ${ }^{1} \mathrm{H}$ NMR $(300 \mathrm{MHz})$ and ${ }^{13} \mathrm{C} \mathrm{NMR}(75 \mathrm{MHz})$ spectra were obtained on a Bruker AC-300 using $\mathrm{CDCl}_{3}$ as solvent and TMS as internal standard. Optical rotations were measured on a Perkin Elmer 341 polarimeter. HPLC analyses were 
performed on a Agilent 1100 series equipped with a chiral column (detailed for each compound below), using mixtures of $n$-hexane/isopropyl alcohol (IPA) as mobile phase, at $25{ }^{\circ} \mathrm{C}$. Analytical TLC was performed on Schleicher \& Schuell F1400/LS silica gel plates and the spots were visualised under UV light $(\lambda=254 \mathrm{~nm})$. For flash chromatography we employed Merck silica gel 60 (0.063-0.2 mm). HRMS was carried out in the Research Technical Services of the University of Alicante.

\section{General procedure for the Michael reaction}

To a mixture of catalyst $7(0.024 \mathrm{~g}, 0.05 \mathrm{mmol})$ and the $\beta$-nitrostyrene derivative $(0.25 \mathrm{mmol})$ in $n$ hexane $(100 \mu \mathrm{L})$ was added the corresponding $\alpha$-alkoxyketone $(0.5 \mathrm{mmol})$ at 0 or $-40{ }^{\circ} \mathrm{C}$. The resulting mixture was stirred at the corresponding temperature until $\beta$-nitrostyrene derivative consumption (TLC monitored). The crude reaction mixture was dissolved in $\mathrm{CH}_{2} \mathrm{Cl}_{2}$ and purified by column chromatography (hexane/ethyl acetate 9:1) to give the pure addition products. Spectroscopic and physical data for products 12, as well as literature reference for known products, follow:

(3S,4R)-syn-3-Methoxy-5-nitro-4-phenylpentan-2-one (syn-12aa). ${ }^{11 \mathrm{a}}$ Colourless oil; $\mathrm{R}_{\mathrm{f}}=0.32$ (hexane/ethyl acetate 4:1); ${ }^{1} \mathrm{H} \mathrm{NMR}\left(300 \mathrm{MHz}, \mathrm{CDCl}_{3}\right): \delta 1.77\left(\mathrm{~s}, 3 \mathrm{H}, \mathrm{OCCH}_{3}\right), 3.45(\mathrm{~s}, 3 \mathrm{H}$, $\mathrm{OCH}_{3}$ ), 3.80-3.93 (m, 2H, CHAr and CHO), 4.66 (dd, J=6.8 Hz, $\left.12.9 \mathrm{~Hz}, 1 \mathrm{H}, \mathrm{HCHNO}\right), 4.93$ (dd, $J=8.4,12.9 \mathrm{~Hz}, 1 \mathrm{H}, \mathrm{HCHNO}), 7.20-7.37(5 \mathrm{H}, \mathrm{ArH}) ;{ }^{13} \mathrm{C} \mathrm{NMR}\left(75 \mathrm{MHz}, \mathrm{CDCl}_{3}\right): \delta 26.6$ $\left(\mathrm{OCCH}_{3}\right), 46.3(\mathrm{CHAr}), 59.8\left(\mathrm{OCH}_{3}\right), 76.5\left(\mathrm{CH}_{2} \mathrm{NO}_{2}\right), 86.7\left(\mathrm{CHOCH}_{3}\right), 128.3(\mathrm{ArCH}), 128.4$ (2xArCH), 128.9 (2xArCH), $134.4(\mathrm{ArC}), 209.9(\mathrm{C}=\mathrm{O})$.

(3S,4S)-anti-3-Methoxy-5-nitro-4-phenylpentan-2-one (anti-12aa). ${ }^{11 a}$ Colourless oil; $\mathrm{R}_{\mathrm{f}}=0.35$ (hexane/ethyl acetate 4:1) ${ }^{1} \mathrm{H}$ NMR $\left(300 \mathrm{MHz}, \mathrm{CDCl}_{3}\right): \delta 2.03\left(\mathrm{~s}, 3 \mathrm{H}, \mathrm{OCCH}_{3}\right), 3.67(\mathrm{~s}, 3 \mathrm{H}$, $\left.\mathrm{OCH}_{3}\right), 3.78-3.91(\mathrm{~m}, 2 \mathrm{H}, \mathrm{CHAr}$ and $\mathrm{CHO}), 4.72(\mathrm{dd}, J=6.8,13.2 \mathrm{~Hz}, 1 \mathrm{H}, \mathrm{HCHNO}), 4.84(\mathrm{dd}, J$ $=5.6,13.4 \mathrm{~Hz}, 1 \mathrm{H}, \mathrm{HCHNO}), 7.23-7.38,5 \mathrm{H}, \mathrm{ArH}) ;{ }^{13} \mathrm{C} \mathrm{NMR}\left(75 \mathrm{MHz}, \mathrm{CDCl}_{3}\right): \delta 26.2\left(\mathrm{OCCH}_{3}\right)$, 45.9 (CHAr), $58.8\left(\mathrm{OCH}_{3}\right), 76.7\left(\mathrm{CH}_{2} \mathrm{NO}_{2}\right), 88.1\left(\mathrm{CHOCH}_{3}\right), 128.1(2 \mathrm{xArCH}), 128.4(\mathrm{ArCH})$, $129.1(2 \mathrm{xArCH}), 135.5(\mathrm{ArC}), 208.1(\mathrm{C}=\mathrm{O})$.

HPLC (Chiralpak AD; $1.0 \mathrm{~mL} / \mathrm{min} ; 96: 4 \mathrm{hex} / \mathrm{IPA}, 210 \mathrm{~nm}) ; \mathrm{t}_{\text {Rmajor }}($ anti-12aa $)=35.4$, $\mathrm{t}_{\mathrm{Rminor}}$ (anti12aa $)=59.2 ; \mathrm{t}_{\text {Rmajor }}(\operatorname{syn}-12 \mathbf{a a})=20.3, \mathrm{t}_{\mathrm{Rminin}}(\operatorname{syn}-12 \mathbf{a a})=30.4$.

4-(4-Chlorophenyl)-3-methoxy-5-nitropentan-2-one (anti-12ab/syn-12ab). Colourless oil; $\mathrm{R}_{\mathrm{f}}=$ 0.36 (hexane/ethyl acetate 4:1); IR (film): v 3305, 3170, 2918, 2833, 1718, 1550, 1491, 1377, 1310, 1186, 1092, $841 \mathrm{~cm}^{-1} ;{ }^{1} \mathrm{H} \mathrm{NMR}\left(300 \mathrm{MHz}, \mathrm{CDCl}_{3}\right): \delta 1.83\left(\mathrm{~s}, 3 \mathrm{H}, \mathrm{OCCH}_{3}\right), 3.46\left(\mathrm{~s}, 3 \mathrm{H}, \mathrm{OCH}_{3}\right)$, 3.86-3.93 (m, 2H, CHAr and CHO), 4.63 (dd, $J=12.9,6.8 \mathrm{~Hz}, 1 \mathrm{H}, H C H N O), 4.89$ (dd, $J=12.9$, $8.1 \mathrm{~Hz}, 1 \mathrm{H}, \mathrm{HCHNO}), 7.21$ (d, $J=8.6 \mathrm{~Hz}, 2 \mathrm{H}, \mathrm{ArH}), 7.29$ (d, $J=8.6 \mathrm{~Hz}, 2 \mathrm{H}, \mathrm{ArH}) ;{ }^{13} \mathrm{C} \mathrm{RMN}(75$ $\left.\mathrm{MHz}, \mathrm{CDCl}_{3}\right): \delta 26.6\left(\mathrm{OCCH}_{3}\right), 45.6(\mathrm{CHAr}), 59.8\left(\mathrm{OCH}_{3}\right), 76.4\left(\mathrm{CH}_{2} \mathrm{NO}_{2}\right), 86.5\left(\mathrm{CHOCH}_{3}\right)$, $129.0(\mathrm{ArCH}), 129.4(\mathrm{ArCH}), 132.8(\mathrm{ArC}), 134.4(\mathrm{ArC}), 209.4(\mathrm{C}=\mathrm{O})$; HRMS $(\mathrm{m} / \mathrm{z})$ : calculated for $\mathrm{C}_{14} \mathrm{H}_{16} \mathrm{NO}_{7}\left(\mathrm{M}^{+}\right): 271.0611$; found 275.0581

HPLC (Chiralpak AD; $1.0 \mathrm{~mL} / \mathrm{min} ; 90: 10 \mathrm{Hex} / \mathrm{IPA}, 210 \mathrm{~nm}) ; \mathrm{t}_{\mathrm{Rminor}}\left(\right.$ anti-12ab) $=9.34$, $\mathrm{t}_{\mathrm{Rmayor}}$ $($ anti-12ab $)=10.1 ; t_{\text {Rmajor }}($ syn-12ab $)=7.1, t_{\text {Rminor }}(\operatorname{syn}-12 \mathbf{a b})=7.8$. 
(3S,4R)-syn-3-Methoxy-5-nitro-4-(2-trifluoromethyl)phenylpentan-2-one (syn-12ac). Colourless oil; $\mathrm{R}_{\mathrm{f}}=0.26$ (hexane/ethyl acetate 4:1); IR (film): $v$ 3345, 3180, 2960, 2837, 1716, 1555, 1455 , 1377, 1310, 1260, 1161, 1106, 1032, $773 \mathrm{~cm}^{-1} ;{ }^{1} \mathrm{H}$ NMR $\left(300 \mathrm{MHz}, \mathrm{CDCl}_{3}\right): \delta 1.95(\mathrm{~s}, 3 \mathrm{H}$, $\left.\mathrm{OCCH}_{3}\right), 3.45\left(\mathrm{~s}, 3 \mathrm{H}, \mathrm{OCH}_{3}\right), 4.11(\mathrm{~d}, J=4.7 \mathrm{~Hz}, 1 \mathrm{H}, \mathrm{ArCH}), 4.53-4.45-4.56(\mathrm{~m}, 2 \mathrm{H}, \mathrm{CHO}$ and HCHNO), 4.93 (dd, $J=11.2,2.6 \mathrm{~Hz}, 1 \mathrm{H}, \mathrm{HCHNO}), 7.41$ (t, $J=7.7 \mathrm{~Hz}, 1 \mathrm{H}, \mathrm{ArH}), 7.58-7.48(\mathrm{~m}$, 1H, ArH), $7.68(\mathrm{~d}, J=7.9 \mathrm{~Hz}, 1 \mathrm{H}, \mathrm{ArH}), 7.85(\mathrm{~d}, J=7.9 \mathrm{~Hz}, 1 \mathrm{H}, \mathrm{ArH}) ;{ }^{13} \mathrm{C} \mathrm{NMR}(75 \mathrm{MHz}$, $\left.\mathrm{CDCl}_{3}\right): \delta 26.7\left(\mathrm{OCCH}_{3}\right), 40.3(\mathrm{CHAr}), 59.7\left(\mathrm{OCH}_{3}\right), 75.6\left(\mathrm{CH}_{2} \mathrm{NO}_{2}\right), 85.7\left(\mathrm{CHOCH}_{3}\right), 126.4$ $(\mathrm{ArCH}), 128.3(\mathrm{ArC}), 129.5(\mathrm{ArCH}), 130.2(\mathrm{ArCH}), 132.3(\mathrm{ArCH}), 133.5(\mathrm{ArC}), 206.8(\mathrm{C}=\mathrm{O})$. HRMS $(m / z)$ calculated for $\mathrm{C}_{14} \mathrm{H}_{16} \mathrm{NO}_{7}\left(\mathrm{M}^{+}\right)$: 305.0875; found 305.0970 .

(3S,4S)-anti-3-Methoxy-5-nitro-4-(2-trifluoromethyl)phenylpentan-2-one (anti-12ac). Colourless oil; $\mathrm{R}_{\mathrm{f}}=0.27$ (hexane/ethyl acetate 4:1); IR (film): $v$ 3345, 3180, 2960, 2837, 1716, 1555, 1455 , 1377, 1310, 1260, 1161, 1106, 1032, $773 \mathrm{~cm}^{-1} ;{ }^{1} \mathrm{H}$ NMR $\left(300 \mathrm{MHz}, \mathrm{CDCl}_{3}\right): \delta 2.24(\mathrm{~s}, 3 \mathrm{H}$, $\left.\mathrm{OCCH}_{3}\right), 3.37\left(\mathrm{~s}, 3 \mathrm{H}, \mathrm{OCH}_{3}\right), 3.96(\mathrm{~d}, J=5.0 \mathrm{~Hz}, 1 \mathrm{H}, \mathrm{CHAr}), 4.39$ (dd, $J=12.7,5.7 \mathrm{~Hz}, 1 \mathrm{H}$, $\mathrm{CHO}$ ), 4.77 (ddd, $\left.J=19.2,13.3,6.6 \mathrm{~Hz}, 2 \mathrm{H}, \mathrm{CH}_{2} \mathrm{NO}\right), 7.46$ (t, $\left.J=7.0 \mathrm{~Hz}, 1 \mathrm{H}, \mathrm{ArH}\right), 7.52-7.67$ (m, 2H, ArH), $7.73(\mathrm{~d}, J=8.0 \mathrm{~Hz}, 1 \mathrm{H}, \mathrm{ArH}) ;{ }^{13} \mathrm{C} \mathrm{NMR}\left(75 \mathrm{MHz}, \mathrm{CDCl}_{3}\right): \delta 26.0\left(\mathrm{OCCH}_{3}\right), 40.1$ (CHAr), $59.4\left(\mathrm{OCH}_{3}\right), 75.2\left(\mathrm{CH}_{2} \mathrm{NO}_{2}\right), 87.5\left(\mathrm{CHOCH}_{3}\right), 126.5(\mathrm{ArCH}), 126.7(\mathrm{ArCH}), 128.3$ (ArC), $129.5(\mathrm{ArCH}), 132.3(\mathrm{ArCH}), 134.9(\mathrm{ArC}), 207.0(\mathrm{C}=\mathrm{O})$; HRMS $(\mathrm{m} / \mathrm{z})$ calculated for $\mathrm{C}_{14} \mathrm{H}_{16} \mathrm{NO}_{7}\left(\mathrm{M}^{+}\right): 305.0875$; found 305.0974 .

HPLC (Chiralpak AD; $1.0 \mathrm{~mL} / \mathrm{min} ; 96: 4 \mathrm{Hex} / \mathrm{IPA}, 210 \mathrm{~nm}) ; \mathrm{t}_{\mathrm{Rminor}}\left(\right.$ anti-12ac) $=22.6$, $\mathrm{t}_{\mathrm{Rmayor}}$ (anti12ac $)=35.8 ; \mathrm{t}_{\text {Rmajor }}($ syn-12ac $)=17.0, \mathrm{t}_{\text {Rminor }}($ syn-12ac $)=18.7$.

(3S,4R)-syn-3-Hydroxy-5-nitro-4-phenylpentan-2-one (syn-12ba). ${ }^{11 \mathrm{a}}$ Colourless oil; $\mathrm{R}_{\mathrm{f}}=0.22$ (hexane/ethyl acetate 4:1); ${ }^{1} \mathrm{H}$ NMR $\left(300 \mathrm{MHz}, \mathrm{CDCl}_{3}\right): \delta 2.17\left(\mathrm{~s}, 3 \mathrm{H}, \mathrm{OCCH}_{3}\right), 3.75(\mathrm{~d}, J=4.8$ $\mathrm{Hz}, 1 \mathrm{H}, \mathrm{CHAr}), 4.03$ (dt, $J=3.0,7.6 \mathrm{~Hz}, 1 \mathrm{H}, \mathrm{CHOH}), 4.66$ (dd, $J=6.8,12.9 \mathrm{~Hz}, 1 \mathrm{H}, H C H N O)$, $4.93(\mathrm{dd}, J=8.4,12.9 \mathrm{~Hz}, 1 \mathrm{H}, \mathrm{HCHNO}), 7.20-7.37$ (5H, ArH); ${ }^{13} \mathrm{C} \mathrm{NMR}\left(75 \mathrm{MHz}, \mathrm{CDCl}_{3}\right): \delta 25.5$ $\left(\mathrm{OCCH}_{3}\right), 45.7$ (CHAr), $76.7\left(\mathrm{CH}_{2} \mathrm{NO}_{2}\right), 77.1(\mathrm{CH}-\mathrm{OH}), 128.5(2 \times \mathrm{ArCH}), 128.7$ (ArCH), 128.9 (2xArCH), 133.8 (ArC), $206.3(\mathrm{C}=\mathrm{O})$.

(3S,4S)-anti-3-Hydroxy-5-nitro-4-phenylpentan-2-one (anti-12ba). ${ }^{11 \mathrm{a}}$ Colourless oil; $\mathrm{R}_{\mathrm{f}}=0.24$ (hexane/ethyl acetate 4:1); ${ }^{1} \mathrm{H} \mathrm{NMR}\left(300 \mathrm{MHz}, \mathrm{CDCl}_{3}\right): \delta 2.03\left(\mathrm{~s}, 3 \mathrm{H}, \mathrm{OCCH}_{3}\right), 3.78-3.91(\mathrm{~m}, 2 \mathrm{H}$, CHAr and $\mathrm{OH}), 4.40-4.43(\mathrm{~m}, 1 \mathrm{H}, \mathrm{CHOH}), 4.74(\mathrm{dd}, J=7.1,13.4 \mathrm{~Hz}, 1 \mathrm{H}, H C H N O), 5.03$ (dd, $J=$ $7.813 .4 \mathrm{~Hz}, 1 \mathrm{H}, \mathrm{HCHNO}), 7.23-7.40(\mathrm{~m}, 5 \mathrm{H}, \mathrm{ArH}) ;{ }^{13} \mathrm{C} \mathrm{NMR}\left(75 \mathrm{MHz}, \mathrm{CDCl}_{3}\right)$ : $\delta 26.2\left(\mathrm{OCCH}_{3}\right)$, 45.9 (CHAr), $76.7\left(\mathrm{CH}_{2} \mathrm{NO}_{2}\right), 88.1\left(\mathrm{CHOCH}_{3}\right), 128.1(2 \mathrm{xArCH}), 128.4(\mathrm{ArCH}), 129.1(2 \mathrm{xArCH})$, 135.5 (ArC), $208.1(\mathrm{C}=\mathrm{O})$.

HPLC (Chiralpak AD; $1.0 \mathrm{~mL} / \mathrm{min} ; 96: 4 \mathrm{Hex} / \mathrm{IPA}, 210 \mathrm{~nm})$; $\mathfrak{t}_{\mathrm{Rminor}}\left(\right.$ anti-12ba) $=98.4$, $\mathrm{t}_{\mathrm{Rmayor}}$ (anti12ba $)=104.6 ; t_{\text {Rminor }}(\operatorname{syn}-\mathbf{1 2 b a})=49.7, t_{\text {Rmajor }}(\operatorname{syn}-\mathbf{1 2 b a})=104.6$.

(3S,4R)-syn-4-(4-Chlorophenyl)-3-hydroxy-5-nitropentan-2-one (syn-12bb). ${ }^{11 a}$ Colourless oil; $\mathrm{R}_{\mathrm{f}}=0.36$ (hexane/ethyl acetate 4:1); ${ }^{1} \mathrm{H} \mathrm{NMR}\left(300 \mathrm{MHz}, \mathrm{CDCl}_{3}\right): \delta 2.21\left(\mathrm{~s}, 3 \mathrm{H}, \mathrm{OCCH}_{3}\right), 3.78(\mathrm{~d}$, $J=4.6 \mathrm{~Hz}, 1 \mathrm{H}, \mathrm{OH}), 4.05(\mathrm{dt}, J=2.8,7.6 \mathrm{~Hz}, 1 \mathrm{H}, \mathrm{CHAr}), 4.56(\mathrm{dd}, J=3.2,4.7 \mathrm{~Hz}, 1 \mathrm{H}, \mathrm{CHOH})$, 4.75 (dd, $J=7.5,13.6 \mathrm{~Hz}, 1 \mathrm{H}, H C H N O), 5.02$ (dd, $J=7.6,13.6 \mathrm{~Hz}, 1 \mathrm{H}, \mathrm{HCHNO}), 7.21-7.31$ (m, $2 \mathrm{H}, \mathrm{ArH}), 7.33-7.40(\mathrm{~m}, 2 \mathrm{H}, \mathrm{ArH}) ;{ }^{13} \mathrm{C} \mathrm{NMR}\left(75 \mathrm{MHz}, \mathrm{CDCl}_{3}\right): \delta 28.3\left(\mathrm{OCCH}_{3}\right), 45.1(\mathrm{CHAr})$, 
$76.8\left(\mathrm{CH}_{2} \mathrm{NO}_{2}\right), 76.9(\mathrm{CH}-\mathrm{OH}), 129.1(2 \mathrm{xArCH}), 129.7(\mathrm{ArCH}), 132.2(2 \mathrm{xArCH}), 134.7(\mathrm{ArC})$, $205.9(\mathrm{C}=\mathrm{O})$.

(3S,4S)-anti-4-(4-Chlorophenyl)-3-hydroxy-5-nitropentan-2-one (anti-12bb). ${ }^{11 a}$ Colourless oil; $\mathrm{R}_{\mathrm{f}}=0.38$ (hexane/ethyl acetate 4:1); ${ }^{1} \mathrm{H} \mathrm{NMR}\left(300 \mathrm{MHz}, \mathrm{CDCl}_{3}\right): \delta 2.19\left(\mathrm{~s}, 3 \mathrm{H}, \mathrm{O}=\mathrm{CCH}_{3}\right), 3.79$ $(\mathrm{d}, J=4.9 \mathrm{~Hz}, 1 \mathrm{H}, \mathrm{OH}), 3.89$ (ddd, $\mathrm{J}=4.5,6.0,8.3 \mathrm{~Hz}, 1 \mathrm{H}, \mathrm{CHAr}$ ), 4.39 (t, $J=4.8 \mathrm{~Hz}, 1 \mathrm{H}$, $\mathrm{CHOH}), 4.64$ (dd, J = 8.6, 13.6 Hz, 1H, HCHNO), 4.77 (dd, J=6.0, 13.6 Hz, 1H, HCHNO), 7.03$7.45(\mathrm{~m}, 5 \mathrm{H}, \mathrm{ArH}) ;{ }^{13} \mathrm{C} \mathrm{NMR}\left(75 \mathrm{MHz}, \mathrm{CDCl}_{3}\right): \delta 26.3\left(\mathrm{OCCH}_{3}\right), 46.1(\mathrm{CHAr}), 75.7\left(\mathrm{CH}_{2} \mathrm{NO}_{2}\right)$, $78.4\left(\mathrm{CHOCH}_{3}\right), 129.4$ (2xArCH), 129.64 (2xArCH), 134.4 (ArC), $135.8(\mathrm{ArC}), 207.4(\mathrm{C}=\mathrm{O})$.

HPLC (Chiralpak AS; $1.0 \mathrm{~mL} / \mathrm{min} ; 90: 10 \mathrm{Hex} / \mathrm{IPA}, 210 \mathrm{~nm}) ; \mathrm{t}_{\mathrm{Rminor}}\left(\right.$ anti-12bb) $=28.8, \mathrm{t}_{\mathrm{Rmayor}}$ $($ anti-12bb $)=38.3 ; t_{\text {Rminor }}($ syn-12bb $)=26.1, t_{\text {Rmajor }}($ syn-12bb $)=56.1$.

(3S,4R)-syn-3-Hydroxy-5-nitro-4-((2-trifluoromethyl)phenyl)pentan-2-one (syn-12bc). ${ }^{11 \mathrm{a}}$ Colourless oil; $\mathrm{R}_{\mathrm{f}}=0.20$ (hexane/ethyl acetate 4:1); ${ }^{1} \mathrm{H} \mathrm{NMR}\left(300 \mathrm{MHz}, \mathrm{CDCl}_{3}\right): \delta 2.07\left(\mathrm{~s}, 3 \mathrm{H}, \mathrm{OCCH}_{3}\right)$, 3.94-4.03 (m, 1H, OH), 4.50-4-60 (m, 2H, CHAr and CHOH), 4.68-4.75 (m, 1H, HCHNO), 5.08$5.03(\mathrm{~m}, 1 \mathrm{H}, \mathrm{HCHNO}), 7.42-7.56(\mathrm{~m}, 2 \mathrm{H}, \mathrm{ArH}), 7.71$ (d, J=7.3 Hz, 1H, ArH), 7.85 (d, J=7.8 Hz, $2 \mathrm{H}, \mathrm{ArH}) ;{ }^{13} \mathrm{C} \mathrm{RMN}\left(75 \mathrm{MHz}, \mathrm{CDCl}_{3}\right): \delta 25.3\left(\mathrm{OCCH}_{3}\right), 39.4(\mathrm{CHAr}), 75.6\left(\mathrm{CH}_{2} \mathrm{NO}_{2}\right), 76.4(\mathrm{CH}-$ $\mathrm{OH}), 128.4$ (2xArCH), $129.8(\mathrm{ArCH}), 132.7$ (ArCH), 133.4(ArC), $206.8(\mathrm{C}=\mathrm{O})$.

(3S,4S)-anti-3-Hydroxy-5-nitro-4-((2-trifluoromethyl)phenyl)pentan-2-one (anti-12bc). ${ }^{11 a}$ Colourless oil; $\mathrm{R}_{\mathrm{f}}=0.23$ (hexane/ethyl acetate 4:1); ${ }^{1} \mathrm{H} \mathrm{NMR}\left(300 \mathrm{MHz}, \mathrm{CDCl}_{3}\right): \delta 2.37\left(\mathrm{~s}, 3 \mathrm{H}, \mathrm{OCCH}_{3}\right), 4.37$ (s, 1H, OH), 4.50-4-60 (m, 2H, CHAr and CHOH), $4.61(\mathrm{dd}, J=6.3,13.7 \mathrm{~Hz}, 1 \mathrm{H}, H C H N O), 4.77$ (dd, $J=7.3,13.9 \mathrm{~Hz}, 1 \mathrm{H}, \mathrm{HCHNO}), 7.39-7.56$ (m, 1H, ArH), 7.63 (t, J=7.6 Hz, 1H, ArH), 7.75 $(\mathrm{d}, J=8.2 \mathrm{~Hz}, 1 \mathrm{H}, \mathrm{ArH}) ; 7.78(\mathrm{~d}, J=7.8 \mathrm{~Hz}, 1 \mathrm{H}, \mathrm{ArH}) ;{ }^{13} \mathrm{C} \mathrm{NMR}\left(75 \mathrm{MHz}, \mathrm{CDCl}_{3}\right): \delta 25.3$ $\left(\mathrm{O}=\mathrm{CCH}_{3}\right), 40.1$ (CHAr), $73.8\left(\mathrm{CH}_{2} \mathrm{NO}_{2}\right), 78.5(\mathrm{CH}-\mathrm{OH}), 124.4(\mathrm{ArCH}), 129.8(\mathrm{ArCH}), 132.7$ $(\mathrm{ArCH}), 133.4(\mathrm{ArC}), 206.9(\mathrm{C}=\mathrm{O})$.

HPLC (Chiralpak OD; $1.0 \mathrm{~mL} / \mathrm{min} ; 90: 10 \mathrm{Hex} / \mathrm{IPA}, 210 \mathrm{~nm}) ; \mathrm{t}_{\text {Rminor }}\left(\right.$ anti-12bc) $=16.6, \mathrm{t}_{\text {Rmayor }}$ $($ anti-12bc $)=23.5 ; t_{\text {Rmajor }}($ syn-12bc $)=9.4, t_{\text {Rminor }}($ syn-12bc $)=11.0$

\section{Acknowledgments}

This research was supported by the Ministerio de Ciencia e Innovación (Projects CTQ200762771/BQU, CTQ2007-65218/BQU and Consolider Ingenio 2010 CSD2007-00006), the Generalitat Valenciana (Project PROMETEO/2009/039, FEDER) and the University of Alicante (UA). S. F. V. thanks the UA for a predoctoral contract.

\section{References}

1. Perlmutter, P. Conjugate Addition Reactions in Organic Synthesis; Pergamon Press: Oxford, 1992. 
2. (a) Trost, B. M. Science 1991, 254, 1471. (b) Sheldon, R. A. Pure Appl. Chem. 2000, 72, 1233.

(c) Trost B. M. Acc. Chem. Res. 2002, 35, 695. (d) Trost, B. M.; Frederiksen, M. U.; Mathias, U.; Rudd, M. T. Angew. Chem. Int. Ed. 2005, 44, 6630. (e) Guillena, G.; Ramón, D. J.; Yus, M. Angew. Chem Int. Ed. 2007, 47, 2358. (f) Guillena, G.; Ramón, D. J.; Yus, M. Chem. Rev. 2010, 110, 1611.

3. (a) Christoffers, J.; Koripelly, G.; Rosiak, A.; Rössle, M. Synthesis 2007, 1279-1300. (b) López, F.; Feringa, B. L. In Asymmetric Synthesis $2^{\text {nd }}$ Edn. Christmann; M.; Bräse S, Eds.; WileyVCH: Weinheim, 2008, pp 83-89.

4. For selected comprehensive books and reviews, see: (a) Dalko, P. I.; Moisan, L. Angew. Chem. Int. Ed. 2004, 43, 5138. (b) Berkessel, A.; Gröger, H. Asymmetric Organocatalysis: From Biomimetic Concepts to Applications in Asymmetric Synthesis; Wiley-VCH: Weinheim, 2005. (c) Kočovský, P.; Malkov, A. V. Tetrahedron 2006, 62, 255 (thematic issue on Organocatalysis in Organic Synthesis, no. 2-3). (d) Pellissier, H. Tetrahedron 2007, 63, 9267. (e) Enantioselective Organocatalysis, Dalko, P. I. Ed.; Wiley-VCH: Weinheim, 2007. (f) List, B. Chem. Rev. 2007, 107, 5413 (Special Issue in Organocatalysis). (g) de Figueiredo, R. M.; Marcia, R.; Christmann, M. Eur. J. Org. Chem. 2007, 2575. (h) Kotsuki, H.; Ikishima, H.; Okuyama, A. Heterocycles 2008, 75, 493. (i) Kotsuki, H.; Ikishima, H.; Okuyama, A. Heterocycles 2008, 75, 757. (j) MacMillan, D. W. C. Nature 2008, 455, 304. (k) Bertelsen, S.; Jørgensen, K. A. Chem. Soc. Rev. 2009, 38, 2178.

5. (a) Almaşi, D.; Alonso, D. A.; Nájera, C. Tetrahedron: Asymmetry 2007, 18, 299. (b) Tsogoeva, S. B. Eur. J. Org. Chem. 2007, 1071. (c) Vicario J. L.; Badia, D.; Carillo L. Synthesis 2007, 2065.

6. (a) Marigo, M.; Jørgensen, K. A. Chem. Commun. 2006, 2001. (b) Guillena, G.; Ramón D. J. Tetrahedron: Asymmetry 2006, 17, 1465.

7. (a) Enders, D.; Grondal, C.; Hüttl, M. R. M. Angew. Chem. Int. Ed. 2007, 46, 1570. (b) Guillena, G.; Ramón, D. J.; Yus, M. Tetrahedron: Asymmetry 2007, 18, 693.

8. (a) Ono, N. The Nitro Group in Organic Synthesis. Wiley-VCH: New York, 2001. (b) Berner, O. M.; Tedeschi, L.; Enders, D. Eur. J. Org. Chem. 2002, 1877.

9. For recent selected reviews on organocatalyzed aldol reactions, see: (a) Guillena, G.; Nájera, C.; Ramón, D. J. Tetrahedron: Asymmetry 2007, 18, 2249. (b) Geary, L. M.; Hultin, P. G. Tetrahedron: Asymmetry 2009, 20, 131. (c) Zlotin, S. G.; Kucherenko, A. S.; Beletskaya, I. P. Russ. Chem. Rev. 2009, 78, 737. (d) Trost, B. M.; Brindle, C. S. Chem. Soc. Rev. 2010, 39, 1600.

10. For selected reviews on organocatalyzed Mannich reactions, see: (a) Notz, W.; Tanaka, F.; Barbas, C. F., III Acc. Chem. Res. 2004, 37, 580. (b) Ting, A.; Schaus, S. E. Eur. J. Org. Chem. 2007, 5797. (c) Verkade, J. M. M.; vanHemert, L. J. C.; Quaedflieg, P. J. L. M.; Rutjes, F. P. J. T. Chem. Soc. Rev. 2008, 37, 29.

11. (a) Andrey, A.; Alexakis, A.; Bernardinelli, G. Org. Lett 2003, 5, 2559. (b) Andrey, A.; Alexakis, A.; Tomassini, A.; Bernardinelli, G. Adv. Synth. Catal. 2004, 346, 1147. (c) Mossé, S.; Alexakis, A. Org. Lett. 2006, 8, 3577. 
12. (a) Xu, Y.; Córdova, A. Chem. Commun. 2006, 460. (b) Xu, Y.; Zou, W.; Sundén H.; Ibrahem, I.; Córdova, A. Adv. Synth. Catal. 2006, 348, 418.

13. Wang, J.; LI, H.; Lou, B.; Zu, L.; Guo, H.; Wang, W. Chem. Eur. J. 2006, 12, 4321.

14. Almaşi, D.; Alonso, D. A.; Gómez-Bengoa, E.; Nagel, Y.; Nájera, C. Eur. J. Org. Chem. 2007, 2328.

15. Zhang, X.-j.; Liu, S.-p.; Lao, J.-h.; Du, G.-j.; Yan, M.; Chan, A. S. C. Tetrahedron: Asymmetry 2009, 20, 1451.

16. Mandal, T.; Zhao, C.-G. Angew. Chem. Int. Ed. 2008, 47, 7714.

17. (a) Guillena, G.; Hita, M. C.; Nájera, C. Tetrahedron: Asymmetry 2006, 17, 729. (b) Gryko, D.; Kowalczyk, B.; Zawadzki, L. Synlett 2006, 1059. (c) Guillena, G.; Hita, M. C.; Nájera, C. Tetrahedron: Asymmetry 2006, 17, 1493; corrigendum: Tetrahedron: Asymmetry 2007, 18, 1031. (d) Guillena, G.; Hita, M. C.; Nájera, C. Tetrahedron: Asymmetry 2006, 17, 1027; corrigendum: Tetrahedron: Asymmetry 2007, 18, 1030. (e) Guizzetti, S.; Benaglia, M,; Pignataro, L.; Puglisi, A. Tetrahedron: Asymmetry 2006, 17, 2754. (f) Guillena, G.; Hita, M. C.; Nájera, C. Tetrahedron: Asymmetry 2007, 18, 1272. (g) Ma, G.-N.; Zhang, Y.-P.; Shi, M. Synthesis 2007, 197. (h) Guizzetti, S.; Benaglia, M.; Raimondi, L.; Celentano, G. Org. Lett. 2007, 9, 1247. (i) Guillena, G.; Hita, M. C.; Nájera, C. Arkivoc 2007, (iv), 260; corrigendum: Arkivoc 2007, (i), 146. (j) Guillena, G.; Hita, M. C.; Nájera, C.; Viózquez. S. F. Tetrahedron: Asymmetry 2007, 18, 2300. (k) Guillena, G.; Hita, M. C.; Nájera, C.; Viózquez. S. F. J. Org. Chem. 2008, 73, 5933. (1) Kucherenko, A. S.; Syutkin, D. E.; Zlotin, S. G. Russ. Chem. Bull. 2008, 57, 591.

18. (a) Guillena, G.; Nájera, C.; Viózquez, S. F. Synlett 2008, 3031. (b) Bradshaw, B.; EtxebarríaJardi, G.; Bonjoch, J.; Viózquez, S. F.; Guillena, G.; Nájera, C. Adv. Synth. Catal. 2009, 351, 2482. 